\title{
Relationship Between Teachers Attitude and College Students Learning
}

\author{
Prof. Dr. Abid Hussain Ch. \\ Professor, Institute of Education and Research, University of the Punjab, Lahore Pakistan \\ Saghir Ahmad \\ $\mathrm{PhD}$ Scholar, Institute of Education and Research, University of the Punjab, Lahore Pakistan
}

Dr. Ayesha Batool

Lecturer (Visiting), Institute of Education and Research, University of the Punjab, Lahore Pakistan

\begin{abstract}
Teacher is the personality who works in educational organizations and enables the learners to achieve psychological, tangible and behavioral goals in lives. Teacher proficiency depends on the attitude. The positive attitude helps teachers to develop a conductive learner's friendly environment in the class. This also casts a fruitful effect on learning of the students. Attitude begin a social construct is influenced by many factors like age, gender and steam of education. The present research is aimed to examine the relationship between teachers' attitude and students learning. To achieve this purpose correlation research method was used. The population of the study included public and private colleges of Lahore District. The sample of two hundred students was selected. Mean, percentages, Pearson- $r, t$-test, and one way ANOVA were used to analyze the data. The findings of study showed that there was positive strong relationship between attitude of teachers and learning of students. It seems that students learning is enhanced due to teacher's good behavior and attitudes in the classroom. The students learn more with the motivation of teachers. The teachers should deal the students with positive and supportive attitude in the classroom and outside the classroom for their better learning.
\end{abstract}

Keywords: Attitude, Student, Teachers, Learning.

DOI: $10.7176 /$ RHSS/9-3-04

\section{Introduction}

Education is the movement that guides the individuals to live a successful life. It develops the ability through information and new ideas enhance capacity, state of mind, understanding and build up character of people to survive in the society with good manners. Teaching is the procedure in which a teacher produces the best talent of society through polishing the abilities of students. He provides the training in academic life as well as he trains the learners for social life. Thus, teacher is considered the vital element in the process of teaching and learning (Kafas, 2009).

Teacher is the personality who works in educational organizations and enables the learners to achieve psychological, tangible and behavioral goals in lives. In 21 st era, the teachers do not just teach the students, deliver lectures, conduct exams, and assign the marks, as well as they play important roles to organizing, managing, counselling, observing and evaluating the students and their different activities. They also influence the people to develop the positive attitudes and create a healthy environment for the betterment of society (Gourneau, 2015).

The significant role of the educator as an operator of progress, bring change, develop understanding and promote tolerance in the society through teaching. It is probably more difficult in this rapid changing and electronic world. The need of progress, from limit patriotism to universalism, from ethnic and social partiality to patience, comprehension and pluralism, from autocracy to democracy system in its different appearances, and from an innovatively partitioned world to a mechanically joined era, places tremendous duties on teachers who take an interest in the embellishment of the characters and brains of the new generation.

It seems that one in five children in any education system experiences learning. Students with special educational needs are not only found in the primary schools, but also in the high secondary schools. It is uncommon for at least one child in five to go on high schools without having reached the generally accepted level of minimal effective literacy. For such children learning difficulties would persist through life, causing problem in everyday life and professional training (Hogg \& Vaughan, 2005).

According to Solomon (2010) students learning can be influenced by many factors. Some of these factors may be students-based, teachers-based, and home based or institutes based. Teachers based can be due to attitudes about students or pupils. When teachers exhibit attitudes towards students with learning or responds them without due thought and patience, students are likely to have self-confidence adversely affected and continue experiencing learning failure. Teachers' attitude towards students can either build students self-confidence. According to Baronand Byrne (2008) teachers are amongst the people potentially affected in determining students' selfconfidence as a learner. Self-confidence is important for learning in all pupils. The self confidence is both a 
consequence and determinant of learning process.

\section{Objectives of the study}

The study was conducted to achieve the following objectives to:

1. find out the level of teachers attitude with students learning at college level.

2. examine the relationship between teachers attitude and students learning.

3. explore the differences in views of respondents regarding relationship between teachers attitudes and students learning in terms of demographic variables, i.e. gender, year, nature of the institution, and programs.

\section{Significance of the Study}

This study may help in many ways: Findings of the study may help student and teachers. This study may helpful for trainers who train the teachers to build the positive attitudes through training sessions. It may provide the streamline to head of the institutions to pay attention on teachers and learners for the betterment of the institution. It may helpful for curriculum developers and policy makers that they keep in mind the importance of teacher attitude for student learning at the time of curriculum development. This study may help teachers to increase the motivational level as well as learning, if the teachers giving the feedback in non-verbal communication style like smiling face, clapping, and shows more interest on every activity of students. By the positive attitude the learning capabilities may be improved of the students.

\section{Literature Review}

A literature review is a body of text that aims to review the critical point of current knowledge including substantive findings as well as theoretical and methodological contribution to a particular topic.

\subsection{Attitude}

Attitude is a way of thinking. It shows what a person feels towards a thing, person or event and behaves on the basis of this attitude. An attitude is a relatively enduring organization of beliefs, feelings, and behavioral tendencies towards socially significant objects, groups, events or symbols (Hogg \& Vaughan, 2005). According to Solomon (2010) an attitude is an eternal, board appraisal of people, things, advertisements or matters. Attitudes are fundamental determinants of our perceptions of, and actions aspects of our social environment. This chapter comprises of all the details and aspects about the concept of attitude and all the related facts about it.

Attitude can direct our practices and adopt the effects of practice on our deeds. A person's attitude towards life is very critical because it helps him to have a better approach and knowledge of life and develops harmony among all the people around him. The personality of a person is developed in the color of his attitude. If attitude is positive he is supposed to be a positive person and vice versa. People are supposed to behave according to their attitude. They do and see things, people and events in the light of their attitude. Apart from all that, attitude is essential to one's social life, the way one interacts with others is determined by their attitude (Ambreen \& Mohyuddin, 2013).

Hogg and Vaughan (2005) described attitude as it is a perpetual judgment of people that people form with the passage of time towards people, environment, things and events along with his own self. Attitude is permanent for it continues over time. A temporary sense cannot be considered an attitude. They also recognized attitude as comparatively lasting so they remain there till end and through all the circumstances. Attitude is also defined as evaluative statements or judgments concern objects, people or events (Robbin \& Judge, 2008).

\subsection{Importance of Attitude}

There have been so many researchers who conducted a number of researches that have demonstrated that there is a significant correlation between attitude and achievements. Attitude is the most important factor in your life. It helps an individual face the ups and downs of life. Attitude influences how a person manages, what so ever viewpoint he may hold in his mind because it has an effect on his performance. Inherently, we have basic structure of attitude and which is formed by us. Promoting a specific positive and negative thought for a long time will always make a permanent space in others' mind. That's why it is said that if a specific attitude is molded it is extremely expected that never comes out of a person. If a person faces failure for so many times in life, he is likely to develop negative attitude towards life (Pappas, 2015).

\subsection{Attitude Measurement}

The most reliable way to know what attitude an individual has of someone or something is to ask him directly. People may not tell truly about their attitudes but when asked, they respond in the way that is acceptable socially. The score of a scale for measuring attitude is used to determine the hidden approach of a person. Moreover, researchers are supposed to get ready for defending the rationality as well as restrictions of their scales in 
presenting it (McLeod, 2009).

\subsection{Direct Observation}

This type of approach suggests observe the behavior of people directly, whose attitude we need to study. This is an objective sort of method and suits a certain kinds of attitude measurement in a particular setting. We can observe a teachers' behavior and his attitude towards his students by observing it, directly. In some situations, it is not possible to use any other kind of method for judging attitudes. For example if a questionnaire is distributed among the students for giving their opinion about their teachers, they may not be as true as they would be if they are observed directly by their behavior towards teachers and what they say about that teacher. This method is not applicable if we want to study the attitude of a large number of people. Moreover, sometimes it is not possible to measure attitude appropriately because people may be having different mood and it does not depict their actual attitude at that time (Minger, 2014).

\subsection{Direct Questioning}

Like the direct observation method, this method also has a few drawbacks, when there is direct questioning respondents have usually too few options (i.e. agree, disagree or neutral) they can choose. This may not depict their real attitude. In addition if people are asked about something or someone they are afraid of, they may not give you the right answer. So it becomes difficult to measure their attitude (Oundo \& Poipoi, 2014).

\subsection{Indirect Measurement}

People do not show their true attitude either due to fear factor or social undesirability. There are a couple of techniques through which their attitude is measured; these methods are indirect methods or projective techniques. In such methods either people do not have any idea about the things that are assessed or maybe they can't have any control of that thing. An individual is put in an ambiguous situation where he is presented an unclear picture and he is supposed to give his input. When he completes his interpretation an inference is deduced (McLeod, 2009).

\subsection{Tools for Developing Positive Attitude}

Positive attitude is essential for achieving anything in life. Students usually fail to realize the importance of knowledge rather they find education as an unwanted burden on then. So eventually they are unable to get education with its true spirit. If students are motivated correctly towards getting educated they develop the sense of knowledge and become a zealous learner. Children behave the way they see their elders behave. If elders show love for learning, children will also do the same. The importance of positive attitude is explained by Columbus Parent magazine which states that if parents value education and make their children realize its importance, kids will also develop a positive attitude toward learning (Minger, 2014).

\subsection{Effect of Teachers on Students Learning}

Learning is the process of getting new knowledge and permanent change in human behavior. Human learning begins before birth and continues until the death. The students learning are not completely the result of their work; learning is affected by many factors and the first one is the attitude of the teacher. Teachers are another form of parents for students. They guide, teach, show students the real world, and prepare them for living a better life outside the educational institution. Many researchers describe the phenomenon that teachers generally teach in the way they got their education. It means that teaching has a great impact on students and their behavior because they are going to have a shade of their teacher's personality all the life. The effective attitudes and actions used by teachers eventually can make a positive transformation on the life of their student (Gourneau, 2015). A positive attitude from the teacher affects the students' motivation, attitude towards colleges work, the student's selfconfidence and as a result of personality development. Teacher student relationship is one main factor in determining the student learning. When students feel much closed with their teachers they fully participate in class activities. They learned things quickly (Fredricks, 2014).

\subsection{Attitude towards Education in Pakistan}

Pakistan has been going through so much in the past couple of years. There are so many different reasons for Pakistan's local uncertainty and these causes are both internal and external. These issues include the frequent military intervention in the state's political matters and issues such as poverty, joblessness, farming, health and literateness also significantly contribute to the economic instability but the actual problem regarding security issues is derived from within the country. There is anxiety and stress in youth and they are apprehensive and worried for their future. They lack positivity in their attitude. Now the safety fears in Pakistan have become the main inner risk and the country desperately needs to find the answer for these domestic safety dangers. Young generation is more interested in settling abroad now. This wave of terrorism has not only jerked the government but also the entire nation. Though the concept of "human security" is comparatively new on the global forum but it is getting 
more and more responsiveness in the third world countries' safety issues. Pakistan has been categorized on the 2nd number among the 34 poorest countries and 17th in education whereas 34th in health per capita outflow in these 34 poorest countries (Qamruzzaman, Iqbal, Zubair, \& Akhtar, 2012).

A research on the current attitude of students towards education shows that the effect of current security condition on the attitude of students towards career has created a desire in students to go abroad and study there. The most chosen land is UK. Another finding of the research also indicates that the current situation of security has also confined the opportunities for future success for young generation. In Pakistan, students would be more interested in going out of country for getting education if they get a chance. But they prefer to go out of country for education rather than settling there and they wish to come back to work here in their country even if they get the chance of studying in a foreign country. If the issue of security is resolved in Pakistan, they are willing to make their career in their own homeland. Male students are more interested in going abroad than female students (Qamruzzaman, lqbal, Zubair, \& Akhtar, 2012).

\section{Research Methodology}

Quantitative approach was used to conduct this research. The design of the study was correlation and survey type in nature. The population of the research consisted of students from public and private colleges of Lahore. Convenient sampling technique was used for the selection of respondents to know the relationship of teachers' attitude and students learning. The size of the sample was 200 students.

\subsection{Instrumentation}

After the literature, articles, documents, a self-developed questionnaire (Relationship of teachers' attitude and students learning of colleges) was used to obtain the information. The information was collected on five point likert type scale. Validity of the questionnaire was ensured through expert opinions.

\subsection{Reliability}

Reliability of the research instrument.

\begin{tabular}{cc} 
Cronbach's Alpha & No. of Items \\
\hline .926 & 24 \\
\hline
\end{tabular}

The table shows the reliability of the research instrument. The questionnaire contained twenty four statements about relationship of teachers' attitude and students learning. The Cronbach's Alpha was applied to check the reliability of the instrument. There were 24 statements and reliability was .926 , which is statistical significant. The value of Cronbach's Alpha showed that the data were reliable to proceed for further analysis.

\subsection{Data Collection and Analysis}

Researchers personally visited all colleges and distributed the questionnaire to the concerned students of the collection of required information. Students of all colleges co-operated. Researcher provided guideline to the students how to fill the questionnaire. Descriptive and inferential statistical analysis techniques were applied to analyze the data. Means and percentages were calculated in the descriptive statistical analysis to know the exact percentage of the subjects. To check the relationship Pearson Product moment was used. One way ANOVA and independent sample t-test were used on demographic variables like gender, programs, year and college type (public and private).

\section{Analysis and Interpretation of Data}

A detail description of data analysis is as under.

Table 1

Gender wise Percentage of Students

\begin{tabular}{clcc}
\hline Gender & & Frequency & Percent \\
\hline & Female & 135 & 67.5 \\
& Male & 65 & 32.5 \\
& Total & 200 & 100.0 \\
\hline
\end{tabular}

Table 1 show that $67.5 \%$ students were female and $32.5 \%$ were male.

Table 2

Sectors wise Students Percentage

\begin{tabular}{ccc}
\hline Sector & Frequency & Percent \\
\hline Public & 100 & 50 \\
Private & 100 & 50 \\
Total & 200 & 100 \\
\hline
\end{tabular}

Table describes that 50\% students were selected from public sector and 50\% students were from private sector 
colleges.

Table 3

Qualification wise Student Responds Percentage

\begin{tabular}{lcc}
\multicolumn{1}{c}{ Program } & Frequency & Percent \\
\hline B.A/B.Sc/B.Com & 40 & 20.0 \\
I.COM & 18 & 9.0 \\
ICS & 44 & 22.0 \\
FA/F.Sc & 98 & 49.0 \\
Total & 200 & 100.0
\end{tabular}

Table 3 shows that $49.0 \%$ students were from F.A/ F.Sc study program, 22\% were from ICS program, $9.0 \%$ from I.Com and $20 \%$ from B.A/B.Sc/B.Com study program.

Table 4

Statistical Values about Teachers Attitude

\begin{tabular}{|c|c|c|c|}
\hline Sr.\# & Statements & $M$ & $S D$ \\
\hline 1 & Teachers allow students to freely express their opinions. & 3.37 & 1.304 \\
\hline 2 & Teachers are friendly and respectful to students learning. & 3.63 & 1.209 \\
\hline 3 & Teachers are establish clear rules from the starting of the course & 3.63 & 1.122 \\
\hline 4 & Teachers allow students to drink and eat in class. & 3.86 & 1.217 \\
\hline 5 & Teachers allow students to leave class to pick up a phone call. & 2.20 & 1.134 \\
\hline 6 & Teachers monitor student's class work by walking around their seats. & 3.71 & 1.180 \\
\hline 7 & Teachers remove students who are causing problems in the class room. & 3.47 & 1.089 \\
\hline 8 & Teachers encourage students to self-evaluate their behavior. & 3.72 & 1.117 \\
\hline 9 & Teachers are welcome student's suggestions for best learning. & 3.69 & 1.195 \\
\hline 10 & Teachers display a strict attitude towards students control in class. & 3.64 & 1.195 \\
\hline 11 & Do you think teacher's appreciation is imperative to up lift student's learning? & 3.47 & 1.177 \\
\hline 12 & Do you think that only reward motivates the student? & 3.32 & 1.302 \\
\hline 13 & Does teacher's politeness welcomes disturbance in class. & 3.69 & 1.100 \\
\hline 14 & Do you think good attitude set the mood of the class once and for all? & 2.46 & 1.271 \\
\hline 15 & $\begin{array}{l}\text { Do you believe that flexibility in the attitude of the teachers produce good } \\
\text { performance? }\end{array}$ & 3.45 & 1.259 \\
\hline
\end{tabular}

Table indicates that majority of students were agreed about the statement that teachers allow students to drink and eat in class $(M=3.86, S D=1.217)$. A very few students disagreed with the statements that teacher good attitude set the mood of the class once and for all $(M=2.46, S D=1.271)$ and they believed that teachers have to allowed students to leave the class to pick up a phone call $(M=2.20, S D=1.134)$.

Table 5

Statistical values about Students Learning

\begin{tabular}{llcc}
\hline Sr.\# & Statements & $\boldsymbol{M}$ & $\boldsymbol{S D}$ \\
\hline $\mathbf{1 6}$ & Do you think teacher's speaking skills affect the productivity of student learning? & 3.87 & 1.113 \\
$\mathbf{1 7}$ & I have trust and confidence in my teachers for best learning. & 3.80 & 1.142 \\
$\mathbf{1 8}$ & Changing teaching methodology according student learning and need. & 3.71 & 1.146 \\
$\mathbf{1 9}$ & Your teacher is impressive personality. & 3.98 & 1.134 \\
$\mathbf{2 0}$ & I think student learning can be enhance due to teachers motivation. & 3.91 & 1.180 \\
$\mathbf{2 1}$ & Teachers use strategies to encourage active learning and participation among & 3.46 & 1.227 \\
& students. & 3.85 & 1.196 \\
$\mathbf{2 2}$ & Teacher's goals and methods address a variety of student learning style. & 3.82 & 1.187 \\
$\mathbf{2 3}$ & Teacher's immediately consult with you to correct problem and complete their & & \\
& learning. & 3.83 & 1.174 \\
$\mathbf{2 4}$ & Teachers encourage learning through group interaction. &
\end{tabular}

Table indicates that majority of students were agreed about the statement that their teachers have impressive personality $(M=3.98, S D=1.134)$. A very few teachers disagreed with the statements that teacher use strategies to encourage active learning and participation among students $(M=3.46, S D=1.227)$ and they believed that teachers should change their teaching methodology according to student need and learning $(M=3.71, S D=1.146)$. 
Table 6

Correlations between Teachers Attitude and Students Learning Score

\begin{tabular}{lccc}
\hline Variables & & Teachers Attitude & Students Learning \\
\hline Teachers Attitude & Pearson Correlation & 1 & $.783^{* *}$ \\
& Sig. (2-tailed) & & .000 \\
& $\mathrm{~N}$ & 200 & 200 \\
\hline
\end{tabular}

Table 6 reveals the correlation between teachers' attitude and students learning by using Pearson productmoment. There was a low positive correlation between two variables, $r=.783, n=200, p=.000)$. It is concluded that in teachers attitude and students learning positively associated with each other at high level. It is concluded that effects of teachers attitude on students learning significantly.

Table 7

Independent Sample t-test for Differences among students about Teacher Attitude and Students Learning on the basis of Gender

\begin{tabular}{|c|c|c|c|c|c|c|c|}
\hline Variables & Gender & $N$ & $M$ & $S D$ & t-value & $d f$ & Sig. \\
\hline \multirow[t]{2}{*}{ Teachers Attitude } & Male & 65 & 43.74 & 6.838 & -.719 & 198 & .473 \\
\hline & Female & 135 & 44.47 & 6.641 & & & \\
\hline \multirow[t]{2}{*}{ Students Learning } & Male & 65 & 40.06 & 8.314 & -1.169 & 198 & .244 \\
\hline & Female & 135 & 41.52 & 8.223 & & & \\
\hline
\end{tabular}

Table 7, in statement 1 an independent sample t-test was applied to find out the difference among the students' scores on the basis of gender. There was no significant difference in score of male $(M=43.74, S D=6.838)$ and female $M=44.47, S D=6.641, t(198)=-.719, p=.473$.

In statement 2 an independent sample t-test was applied to find out the difference between students learning on the basis of gender. There was no significant difference in score of male $(M=40.06, S D=8.314)$ and female $M$ $=41.52, S D=8.223, t(198)=-1.169, p=.244$. It was concluded that both female and male students had no difference in the opinion about teachers' attitude and students learning at college level.

Table 8

Independent Sample t-test for Differences among Students about Teacher Attitude and Students Learning on the basis of Class Year

\begin{tabular}{lccccccc}
\hline Variables & Year & $\boldsymbol{N}$ & $\boldsymbol{M}$ & $\boldsymbol{S D}$ & $\boldsymbol{t}$-value & $\boldsymbol{d} \boldsymbol{f}$ & Sig. \\
\hline Teachers Attitude & 1 & 105 & 44.03 & 6.947 & -.446 & 198 & .656 \\
Students Learning & 2 & 95 & 44.45 & 6.439 & & & \\
& 1 & 105 & 39.99 & 8.291 & -1.911 & 198 & .057 \\
\hline
\end{tabular}

Table 8 , in statement 1 an independent sample t-test was applied to find out the difference between the students' scores on the basis of their class year. There was no significant difference in score of first year $(M=44.03$, $S D=6.947)$ and second year $M=44.45, S D=6.439, t(198)=-.446, p=.656$.

In statement 2 an independent sample t-test was applied to find out the difference between students learning on the basis of class year. There was no significant difference in score of first year $(M=39.99, S D=8.291)$ and second year $M=42.21, S D=8.111, t(198)=-1.911, p=.057$. It was concluded that both first year and second year students had no difference in the opinion about teachers' attitude students learning at college level.

Table 9

Independent Sample t-test for Differences among students about Teacher Attitude and Students Learning on the basis of College Type

\begin{tabular}{llcccccc}
\hline Variables & Sector & $\boldsymbol{N}$ & $\boldsymbol{M}$ & $\boldsymbol{S D}$ & $\boldsymbol{t}$-value & $\boldsymbol{d} \boldsymbol{f}$ & Sig. \\
\hline Teachers Attitude & Private & 100 & 44.31 & 6.955 & .169 & 198 & .866 \\
& Public & 100 & 44.15 & 6.463 & & & \\
Students Learning & Private & 100 & 41.06 & 8.742 & .026 & 198 & .980 \\
& Public & 100 & 41.03 & 7.793 & & & \\
\hline
\end{tabular}

Table 9, in statement 1 an independent sample t-test was applied to find out the difference between the students' scores on the basis of their college type. There was no significant difference in score of private $(M=44.31$, $S D=6.955)$ and public $M=44.15, S D=6.463, t(198)=.169, p=.866$.

In statement 2 an independent sample t-test was applied to find out the difference between students learning on the basis of college type. There was no significant difference in score of private $(M=41.06, S D=8.742)$ and public $M=41.03, S D=7.793, t(198)=.026, p=.980$. It was concluded that both private and public sector college students had no difference in the opinion about teachers' attitude students learning at college level. 
Table 10

ANOVA for the Difference in the Mean Scores of Attitude towards Innovative Teaching Methodologies of Teachers on the Basis of Program

\begin{tabular}{llccccc}
\hline Variables & & Sum of Squares & $\boldsymbol{d} \boldsymbol{f}$ & Mean Square & $\boldsymbol{F}$ & Sig. \\
\hline Teachers & Between Groups & 51.330 & 3 & 17.110 & .378 & .769 \\
Attitude & Within Groups & 8874.090 & 196 & 45.276 & & \\
& Total & 8925.420 & 199 & & & \\
Students & Between Groups & 261.526 & 3 & 87.175 & 1.283 & .281 \\
Learning & Within Groups & 13317.069 & 196 & 67.944 & & \\
& Total & 13578.595 & 199 & & & \\
\hline
\end{tabular}

Table 10 shows that a one way ANOVA was applied to explore the difference in means scores of teachers attitude and students learning through perception of colleges students the value of teachers attitude: $F(3,196)$ $=.378, p=.769$ and students learning: $F(3,196)=1.283, p=.281$.

There was no significant difference in the result of teachers' attitude and students learning. Therefore it is concluded that having different programs does not affect significantly on teachers attitude and students learning at college level.

\section{Conclusion}

This study was conducted to investigate the relationship between teachers' attitude and students learning. It is concluded from the study that if teachers are showing the negative attitude such as pay no attention on students learning, no motivational activities, not helping for the students learning, can the cause of student failure. It is stated that positive attitude of teachers creates positive relationship with students learning, and negative attitude creates negative relationship. Teachers' attitude mostly effected on student learning. Policy makers and institutional administrators spend the efforts to develop the positive attitude of faculty members. From the findings it is also concluded that there was no significant difference between male and female students' opinions regarding teachers' attitude and their learning. It can also be concluded that teachers' positive attitude and learning of students both are the compulsory to achieve the educational goals and compete in the educational markets.

\section{Recommendations}

This paragraph is based upon the some recommendations that may be helpful for personnel and institutions. Teachers may encourage students and congratulations them on their success. They should make themselves available for guidance of the students. They may use the latest methodology to help the students in easier learning. Teachers might be capable enough to point out the negative changes in attitude of students so that it can be rectified in the beginning. They should try to make students more responsible for their learning by planning the different activities to involve them. The teachers may deal the students with positive and supportive attitude in the classroom and outside the classroom for their better learnings.

\section{References}

Ambreen, M., \& Mohyuddin, A. (2013). Gender biased parental attitudes towards education: A case study of village dasuha, district Faisalabad. Academic Research International, 4(3), 140-147.

Baron, R., \& Byrne, D. (2008). Social psychology. Pearson Education, 4(1), 52.

Fredricks, J. A., Blumenfeld, P. C., \& Paris, A. H. (2004). School engagement: Potential of the concept, state of the evidence. Review of Educational Research, 74(1), 59-109.

Gourneau, B. (2015). Five attitudes of effective teachers: Implications for Teacher Training, 3(1), 1-8.

Hogg, M., \& Vaughan, G. (2005). Psychological discourse in advertising. Social Psychology, 2(4), 1-50.

McLeod, S. (2009). Psychology attitude measurement. Retrieved October 07, 2015, from simplypsychology.org:http//www.simplypsychology.org/attitude-measurement.html

Jain, V. (2014). 3d model of attitude. International Journal of Advanced Research in Management and Social Sciences, 2(1), 1-12.

Kafas, P. (2009). Child neglect: A review. The Internet Journal of Forensic Sciences, 92, 4-60.

Minger, D. (2014). Promote positive attitudes towards school. Retrieved October 7, 2017, from livestrong.com: http//WWW.livestrong.com/article/83701.

Oundo, M., \& Poipoi, M. (2014). Relationship between parent attitude towards educational involvement and academic performance of day secondary school in Samia-Kenya, 7(1), 147-157.

Pappas, C. (21015). Eleven tips for e-learning professional. Retrieved October 7, 2015, from how to encourage positive attitude in learning.

Qamruzzaman, Iqbal, M., Zubair, M., \& Akhtar, S. (2012). Impact of current security condition on students, 7(4), 93-101.

Robbin, S. P., \& Judge, T. A. (2008). Organizational Behavior. Companile Drive San Diedo: Prentice Hall. 
Solomon, S. (2010). Effectiveness of an educational intervention on medical students' knowledge about and attitude towards electroconvulsive therapy. Journal of educational philosophy, 10(7), 327. 